\section{STATIC FAILURE OF THE ADHESIVE AND COMBINATION JOINTS ON COLD-FORMED STEEL JOINT USING A COHESIVE ZONE MODEL APPROACH}

Siti Nur Rahmah Anwara,b*, Priyo Suproboc, Endah Wahyunic, Faimunc, Siti Aminah Anward

aCivil Engineering Department of Universitas Mataram (UNRAM), Indonesia

bMagistry of Civil Engineering, Universitas Mataram (UNRAM), Indonesia

cCivil Engineering Department, Institut Teknologi Sepuluh Nopember (ITS), Surabaya, Indonesia

dEconomics Faculty of Universitas Islam Malang (UNISMA), Indonesia
Article history

Received

23 September 2015

Received in revised form

18 June 2018

Accepted

1 August 2018

Published online

15 December 2018

*Corresponding author rahmah_snra@yahoo.co.id

\section{Graphical abstract}
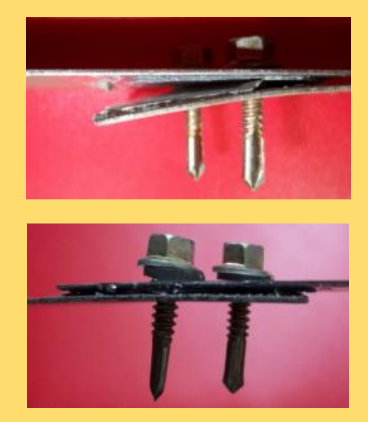

\section{Abstract}

A research of new connection method due to axially static loading on the cold-formed steel in civil engineering structures has been investigated. Joint failure was modeled with a cohesive zone model (CZM) approach where the governing parameters were determined from fracture mechanics test specimens. The incremental in capacity strength of coldformed steel single lap joints (SLJS) was successfully predicted. Video microscope records carried out on the failure surface of the joints in experimental works. The modeling results have a good correlation with the experimental works. Strength capacity deviation of experimentation to FEM are $21.93 \%, 18.5 \%, 36.3 \%, 12.47 \%$ and $4.03 \%$ for srew, epoxy resi adhesive, polyester resin adhesive, combination screw with epoxy resin and combination screw with polyester resin connections.

Keywords: Cold-formed steel, adhesive joint, combination joint, failure, axial strength, cohesive zone model

(c) 2019 Penerbit UTM Press. All rights reserved

\subsection{INTRODUCTION}

Cold-formed steel sections have been used in bridge construction, drainage facilities, metalic building of industries, residential construction, automotive and others applications. Cold-form steel structure joints generally use self drilling screw to easy installing and providing a rapid joint. Nowadays, a premature collapse of cold formed steel structures could be occurred, eventhough during erection process. This phenomena might be caused by local buckling, torsion buckling, lateral buckling and residual stresses of coldformed steel, $[1,2,3,4,5,6,7,8]$ Adhesive joint is also used in various industries because of the advantages over the mechanical fastening such as screwing, riveting, welding and bolting, $[9,10,11,12,13,14,15$, 16]. Thin elements of cold-formedsteel have a high slenderness, that it causes the local buckling. Screw as the origin connection of cold-formed elements has a weakness of screw thread by looping rotation. The advantages of adhesive joint to others forms of connection are an improving mechanical response, the ability to bond dissimilar materials and the ability to distribute the stresses uniformly [17]. Considering the advantages of adhesive and the weakness of screw connection, the major concern in this research is using adhesive joint and combination joint on cold-formed steel structures due axial loading. 
Experimental data on capacity strength of single lap joints (SLJs) due to axial loading obtained by Anwar SNR et.al [18] concluded that capacity strength of single lap joints (SLJs) cold-formed steel was increased significantly by using adhesive in the joints. Materials test of $\operatorname{SLJ}$ is regulated by $\operatorname{ASTM}(19,20]$.

The one of approaches of damage modeling is a cohesive zone model (CZM) approach. A CZM is used in this paper because the crack path is generally constrained in the adhesive layer. The aim of the current study was to investigate use of a CZM approach to predict the capacity strength of adhesive joint and combination joint on the single lap joints (SLJs). This research extends the previous work of the authors [21], which introduced axial performance of cold-formed steel structures by adhesive bonding.

\subsection{METHODOLOGY}

Research methods consist of two steps; are experimentation and finite element modelling (FEM) as shown in Figure 1.

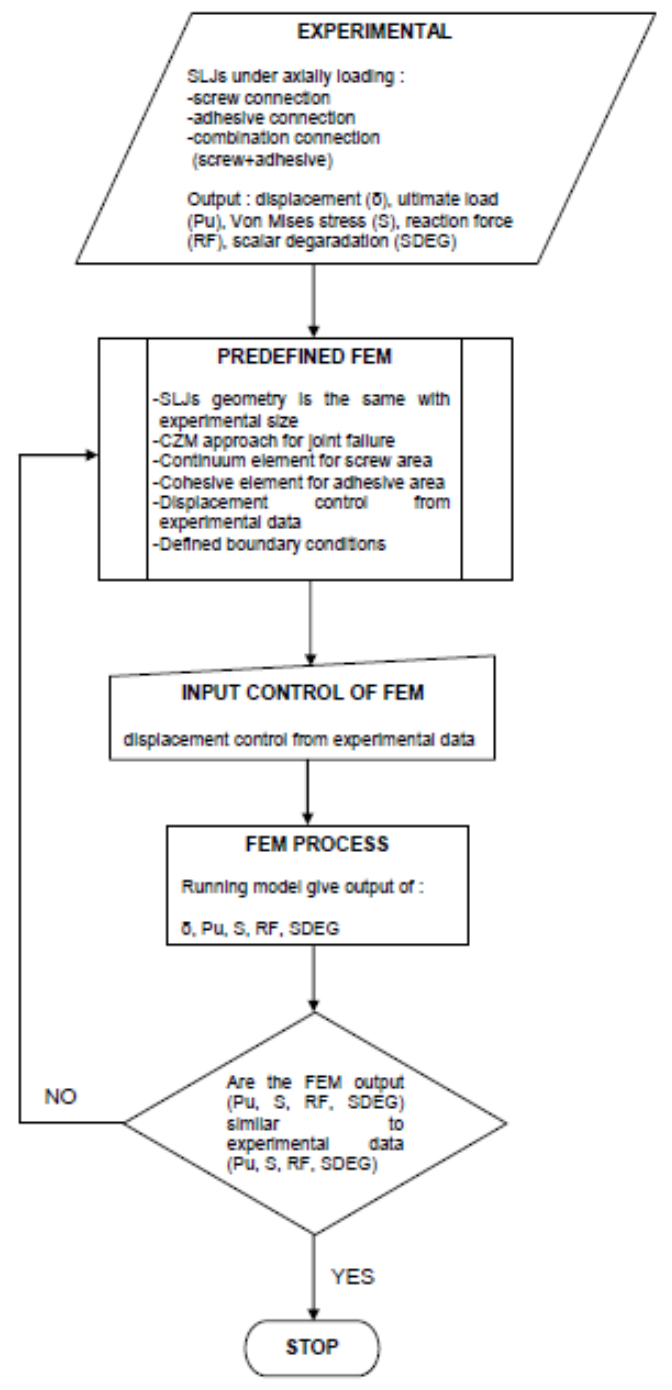

Figure 1 Flowchart of research method

\subsection{Experimentation}

In this study, the enhanced strength on the single lap joint of adhesive bonded cold-formed steel and combination joint has been investigated. Screw joint of $S L J$ is used as a comparator of the incremental strength.

\subsubsection{Materials Properties of the Joints}

Various test procedures were employed to obtain the mechanical properties of epoxy resin adhesive and polyesther resin adhesive. Experiments were conducted on bulk adhesives and adhesive bonded of single lap joints (SLJS). To produce the maximum joints strength, surfaces of cold-formed steel were roughened using a maximum grade abrasive paper.

\section{Adhesives}

Bulk adhesives and adhesive bonded cold-formed joints of single lap joint (SLJ) were used in the experimental work. Bulk adhesives of $0.75 \mathrm{~mm}$ thickness were manufactured for each types of adhesive to obtain the tensile strength and compressive strength of adhesive, as a comparator to the data product of adhesive. A specimen thickness of $0.75 \mathrm{~mm}$ adhesive was maintained using glass spacers.

\section{Cold Formed Steel}

The elastic modulus of cold-formed steel was determined with a tensile test and was found to be $203000 \mathrm{Mpa}$ (Figure 2). The Poisson's ratio obtained was 0.3 .

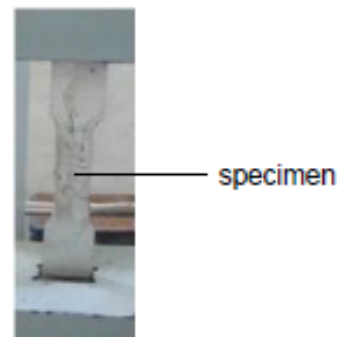

Figure 2 Tensile test coupon of cold-formed steel

\subsubsection{Joint Tests}

The joints tested in this research were made of coldformed steel substrates of $0.75 \mathrm{~mm}$ thickness each, were bonded with epoxy resin adhesive and polyester resin adhesive of $0.75 \mathrm{~mm}$ thickness to manufacture the single lap joints (SLJs). Screw joint of $4 \mathrm{~mm}$ diameter, adhesive were applied on the joints. The dimensions of the joints are illustrated in the Figure 3. 


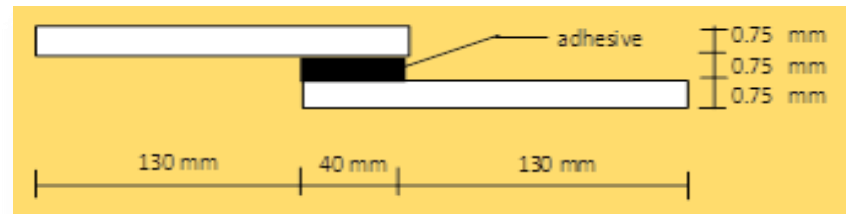

Figure 3 Dimension of single lap joint (SLJ) specimen of $42 \mathrm{~mm}$ width

A variety of joints was screw joint, adhesive joint and combination joint of screw with adhesive. The dimension of lap joint tests are shown in Figure 4. The screw diameter and adhesive thickness were $4 \mathrm{~mm}$ and $0.75 \mathrm{~mm}$ respectively.

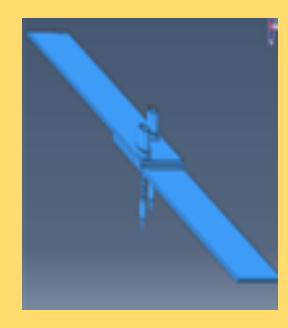

(a)

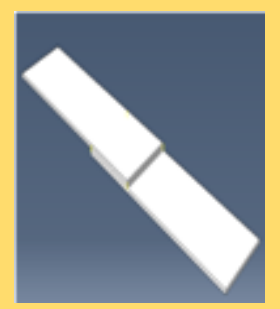

(b)

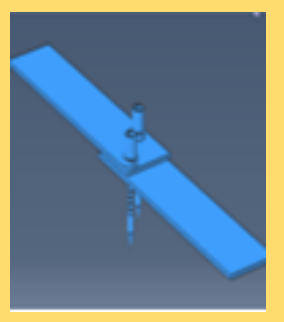

(c)
Figure 4 Joints SLJ; (a) screw joint, (b) adhesive joint, (c) combination of screw with adhesive joint

A device (jig) was used to control the position of the SLJs substrates, the bond line thickness and the appropriate pressure of joints. The substrates, adhesive layers and the spacers were pressed in the jig. The joints consist of three types; screw joint, adhesive joint and combination of screw with adhesive joint. The adhesive thickness was set up to $0.75 \mathrm{~mm}$.

\subsection{Testing Specimen}

Static loading testings were carried out on the bulk adhesive specimens (Figure 5) and joint specimens (Figure 6). The ultimate strength and strain due axial loading of the joints were measured. Visual investigation and video microscope recorder were used to describe the joints failure.

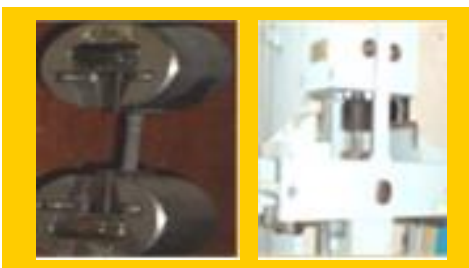

(a)

(b)

Figure $\mathbf{5}$ Test of adhesive material; (a) tensile test, (b) compressive test

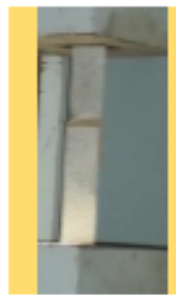

(a)

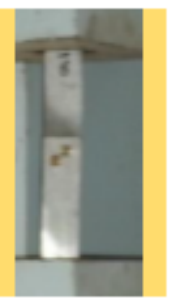

(b)
Figure 6 Axially test of single lap joints (SLJS)

\subsection{Finite Element Modeling}

The failure response of the joints was simulated using a cohesive zone model (CZM). A two-parameter CZM was used where separations in mode I, II and III were defined for. The cohesive parameters are the energy and the tripping traction. The unloading stiffness was set high to avoid any compliance of the CZM element before the initial damage (Figure 7). The licensed software of ABAQUS was used for the numerical modeling work. The CZM parameters were determined from the tensile test of adhesives (epoxy resin and polyester resin). The tripping traction was determined by the initial non-linearity in the load displacement response. The fracture energy was then obtained by correlating the simulated load-crack length with the experimental results. The CZM properties carried in a region that ensured the mesh independence.

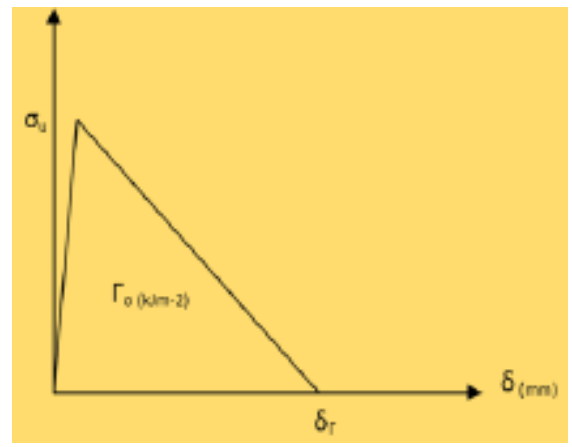

Figure 7 Shape of the cohesive zone model; displacement $(\delta)$ and tripping traction $\left(\sigma_{u}\right)$

The SLJs was modeled with 3D as the screw and adhesive was constrained by the substrates. The mesh used for 3D model can be seen in Figure 8. The smallest elements is $5.25 \times 5 \times 0.75 \mathrm{~mm}$. Four-node linear tetrahedron (C3D4), eight-node linear (C3D8H) and eight-node three-dimensional cohesive elements (COH3D8) were used for models. 


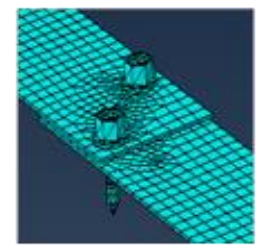

(a)

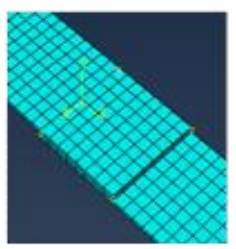

(b)

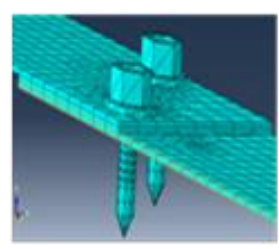

(c)
Figure 8 Mesh used for 3D model of the SLJ; (a) screw joint, (b) adhesive joint, (c) combination joint

\subsection{RESULTS AND DISCUSSION}

Experimental results based on adhesive materials testing, bulk adhesive testing, static rupture test of joints, and investigation of progressive damage on the joints.

\subsection{Materials Properties}

The compressive strength test of adhesive is measured by the ASTM D695 recommendation of Standard Test Method for Compression Properties of Rigid Plastics. Cylindrical specimens dimension is 1 in of diameter, 2 in of height (Figure 9); or prism specimens dimension is 0.5 in of width, 0.5 inch of height and 1 inch of thick. The compressive strength of polyester resin adhesive does not need a compression testing because its material's failure is a ductile failure. A polyester resin is a combination of resin and fiber which is the tensile strength very dominant rather than the compressive strength. The compressive strength of epoxy resin is shown in Table 1.

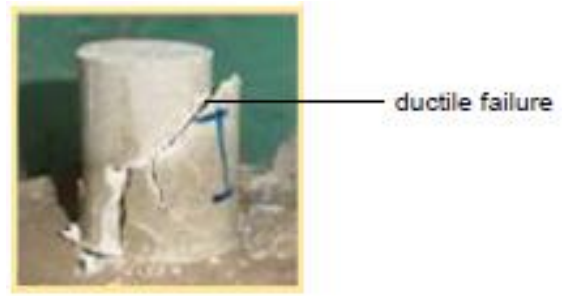

Figure 9 Adhesive failure of epoxy resin specimens

Table 1 Compressive strength of epoxy resin adhesive

\begin{tabular}{|c|c|c|c|c|}
\hline No & $\begin{array}{c}\text { Diametre } \\
(\mathbf{m m})\end{array}$ & $\begin{array}{c}\text { Height } \\
\mathbf{( m m})\end{array}$ & $\begin{array}{c}\text { Ultimate } \\
\text { Load (N) }\end{array}$ & $\begin{array}{c}\text { Compressive } \\
\text { Strength (MPa) }\end{array}$ \\
\hline 1 & 20.2 & 40.4 & 14600 & 45.54 \\
\hline 2 & 20.2 & 40.4 & 13700 & 42.73 \\
\hline 3 & 20.2 & 40.4 & 16860 & 52.60 \\
\hline 4 & 20.2 & 40.4 & 17950 & 56.00 \\
\hline
\end{tabular}

Table 2 Tensile strength of epoxy resin and polyester resin adhesives

\begin{tabular}{|c|c|c|c|c|}
\hline Sample & Adhesive & $\begin{array}{l}\text { Thickness } \\
\text { (mm) }\end{array}$ & $\begin{array}{l}\text { Wide } \\
(\mathrm{mm})\end{array}$ & $\begin{array}{c}\text { Tensile } \\
\text { Strength (Mpa) }\end{array}$ \\
\hline 1 & \multirow{3}{*}{$\begin{array}{l}\text { Epoxy } \\
\text { Resin }\end{array}$} & 5 & 10 & 20 \\
\hline 2 & & 5 & 10 & 16 \\
\hline 3 & & 5 & 10 & 19.6 \\
\hline
\end{tabular}

\begin{tabular}{|c|c|c|c|c|}
\hline Sample & Adhesive & $\begin{array}{c}\text { Thickness } \\
(\mathrm{mm})\end{array}$ & \begin{tabular}{|l}
$\begin{array}{l}\text { Wide } \\
(\mathrm{mm})\end{array}$ \\
\end{tabular} & $\begin{array}{c}\text { Tensile } \\
\text { Strength (Mpa) }\end{array}$ \\
\hline 1 & \multirow{3}{*}{$\begin{array}{l}\text { Polyesther } \\
\text { Resin }\end{array}$} & 5 & 10 & 26.5 \\
\hline 2 & & 5 & 10 & 22 \\
\hline 3 & & 5 & 10 & 25 \\
\hline
\end{tabular}

Table 2 shows the tensile strength of epoxy resin and polyester resin adhesives. The values of fracture energy of epoxy resin adhesive and polyester resin obtained respectively by $1.4 \mathrm{~kJ}(\mathrm{Nm})$ and $2.5 \mathrm{~kJ}(\mathrm{Nm})$. While the Poisson's ratio $(v)$ of epoxy resin and polyester resin adhesives were 0.28 and 0.3 .

Cold-formed steel of $0.75 \mathrm{~mm}$ thick was used as the substrates of joints. Tensile strength of cold-formed steel refers to ASTM-E8 recommendation, as shown in Table 3. The tensile strength of manufacture data is $656 \mathrm{~N} / \mathrm{mm}^{2}$.

Table 3 Tensile strength of cold-formed steel

\begin{tabular}{|c|c|c|c|}
\hline No & $\begin{array}{c}\text { Width } \\
(\mathbf{m m})\end{array}$ & $\begin{array}{c}\text { Thickness } \\
(\mathbf{m m})\end{array}$ & $\begin{array}{c}\text { Tensile Strength (N/ } \\
\mathbf{m m} \mathbf{)})\end{array}$ \\
\hline 1 & 29.85 & 0.75 & 492.5 \\
\hline 2 & 29.85 & 0.75 & 502.5 \\
\hline 3 & 29.95 & 0.75 & 496.4 \\
\hline
\end{tabular}

\subsection{Axial Strength of Single Lap Joint Specimens}

Based on static rupture test of single lap joint specimens (SLJS), load versus displacement curve is presented in Figure 10 below. Adhesive joints increases the load capacity of joints significantly, exceed than the screw joints capacity.

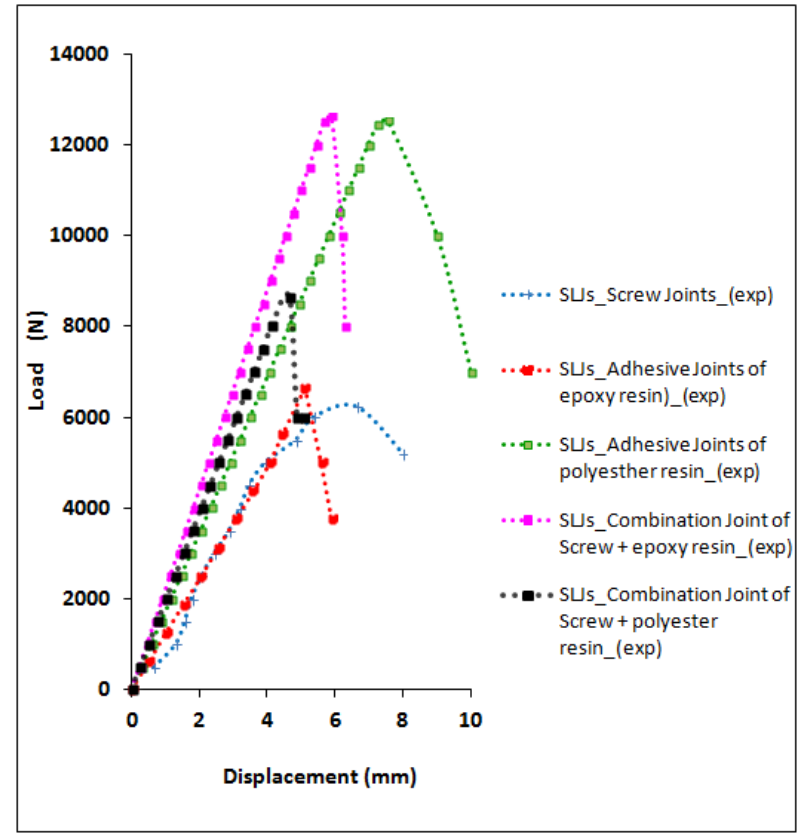

Figure10 Load-displacement curve of SLJs due to axially static loading 
Table 4 Load capacity of axial joints

\begin{tabular}{|l|c|c|}
\hline \multicolumn{1}{|c|}{ Type of Joint } & $\begin{array}{l}\text { Ultimate } \\
\text { Load, Pu (N) }\end{array}$ & $\begin{array}{c}\text { Increment of Pu } \\
\text { (\%) }\end{array}$ \\
\hline Screw & 6240 & 0 \\
\hline Epoxy resin adhesive & 6650 & 7 \\
\hline Polyester resin adhesive & 12450 & 99 \\
\hline $\begin{array}{l}\text { Combination the screw and } \\
\text { epoxy resin adhesive }\end{array}$ & 12630 & 102 \\
\hline $\begin{array}{l}\text { Combination the screw and } \\
\text { polyester resin adhesive }\end{array}$ & 8650 & 39 \\
\hline
\end{tabular}

The relationship between joint types and load capacity is shown in Table 4 . The axial capacity of coldformed steel has increased significantly on the combination joint between screw and adhesive, compared to the screw connection. An anomalous was occurrred on the combination joint between screw and polyester resin adhesive, the strength capacity of joint was not increased higher than epoxy resin adhesive. The drilling screw might cause a few materials of polyester resin adhesive move out from the joint area become fillets corner at the joint.

\subsection{Finite Element Modeling of Single Lap Joint Specimens Due to Axial Loading}

\subsubsection{Screw Joint of SLJS}

Using displacement control of $2.5 \mathrm{~mm}$ (Figure 11) based on experimental data, the SLJs with screw joints give the reaction force of $4871.57 \mathrm{~N}$ (Figure 12) and Von Mises stress of 497.13 Mpa (Figure 13).
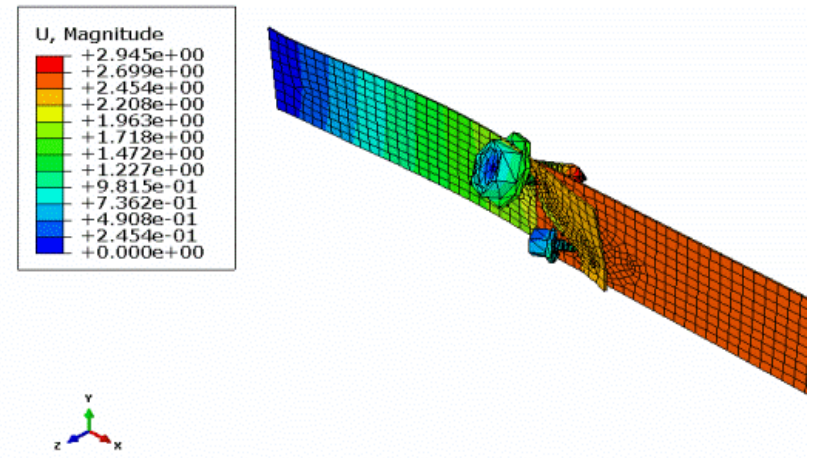

Figure 11 Displacement of single lap joint with screw connection due to static loading
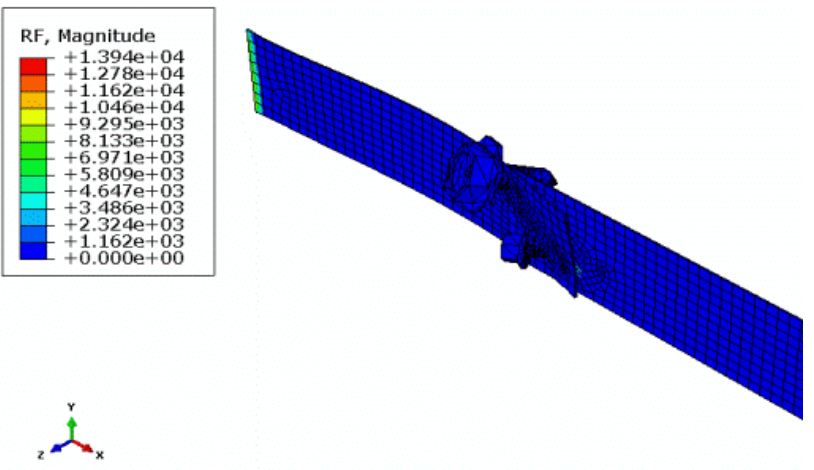

Figure 12 Reaction force of single lap joint with screw connection due to static loading

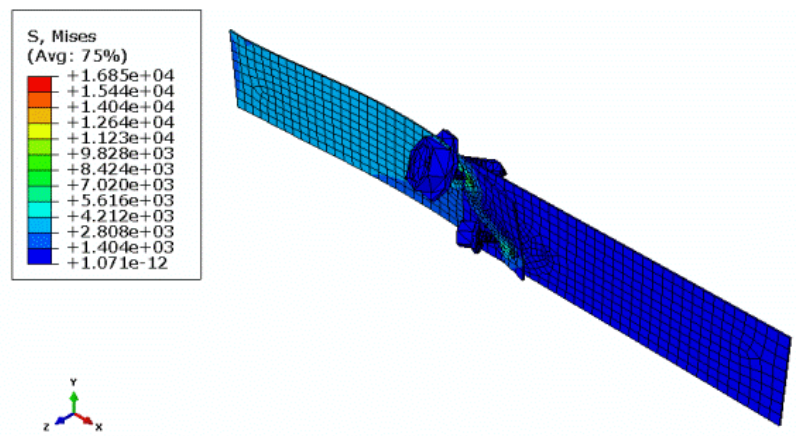

Figure 13 Stress distribution of single lap joint with screw connection due to static loading

\subsubsection{Adhesive joint of SLJS}

Epoxy Resin Adhesive Joint of SLJs

Static response of SLJs with epoxy resin adhesive joint were $7880.48 \mathrm{~N}$ of reaction force (Figure 15) and 804,18 Mpa of Von Mises stress (Figure 16), under $4,5 \mathrm{~mm}$ of displacement control (Figure 14). The degradation of adhesive joint is begun at the ends of the joint, and then it propagate to the middle until rupture, Figure 17.

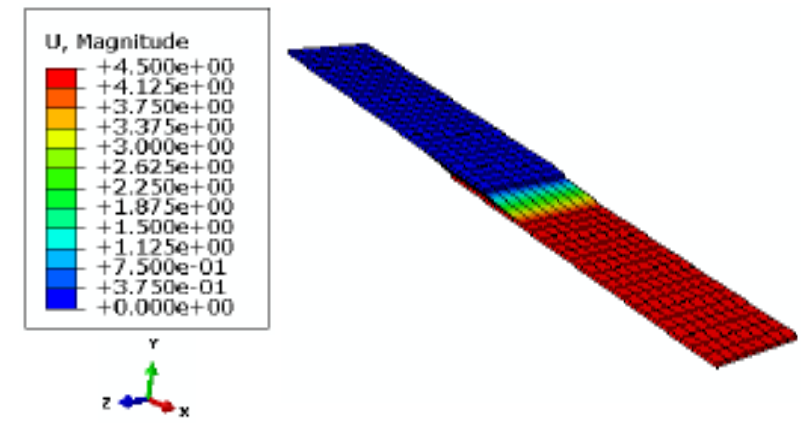

Figure 14 Deformation of single lap joint with adhesive (epoxy resin) connection due to static loading 

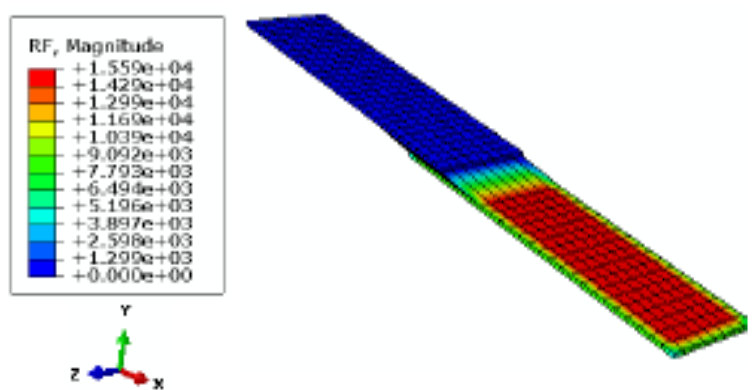

Figure 15 Reaction force of single lap joint with adhesive (epoxy resin) connection due to static loading
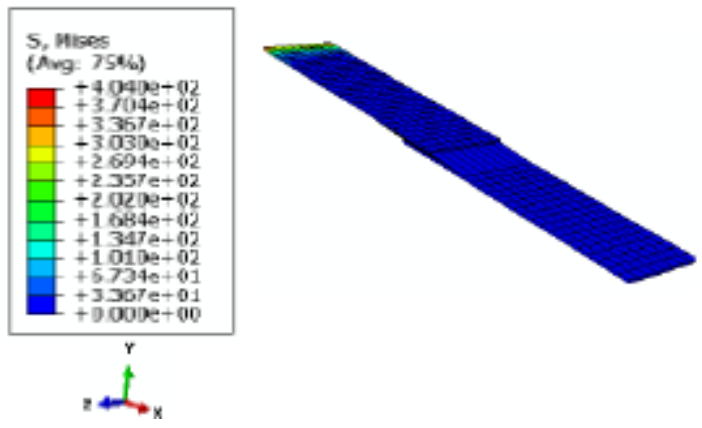

Figure 16 Stress distribution of single lap joint with adhesive (epoxy resin) connection due to static loading

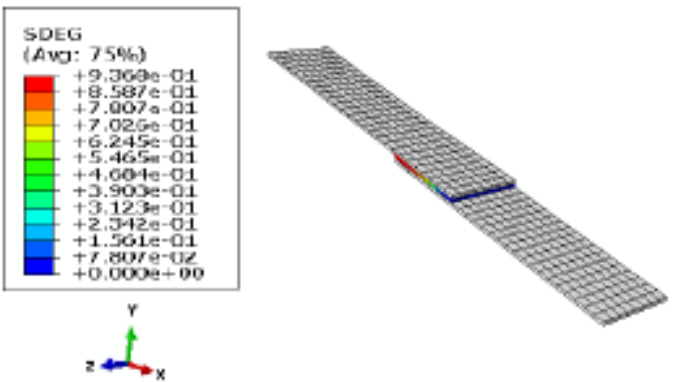

(a)

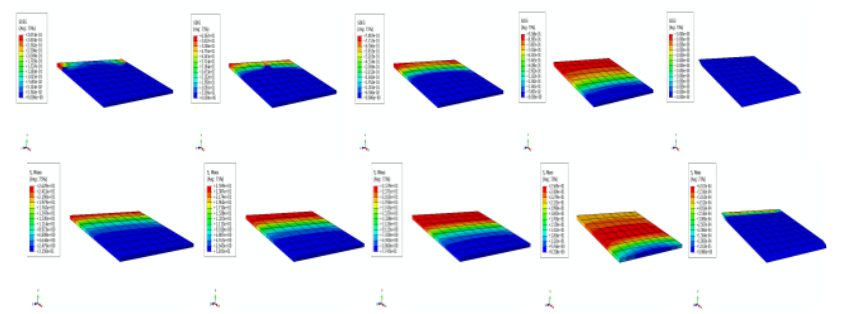

(b)

Figure 17 (a) Damage process of single lap joint with adhesive (epoxy resin) connection due to static loading (b) damage process and stress distribution of joint area from first until final step (left to right direction)
Polyester Resin Adhesive Joint of SLJs

While the single lap joint with polyester resin adhesive gives the reaction force of $7889.48 \mathrm{~N}$ (Figure 19) and Von Mises stress of $805.10 \mathrm{Mpa}$ (Figure 20) under displacement control of $7.5 \mathrm{~mm}$ (Figure 18).

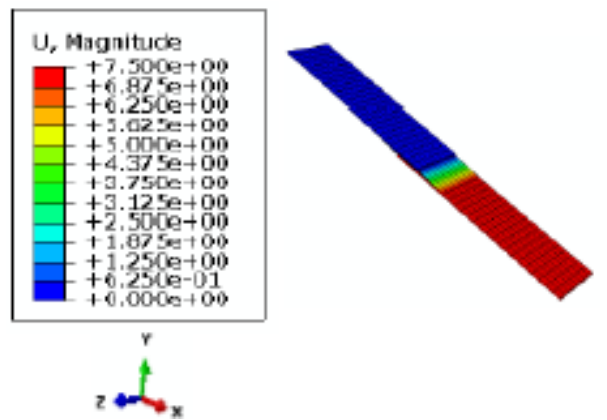

Figure 18 Displacement of SLJ with adhesive (polyester resin) connection due to static loading

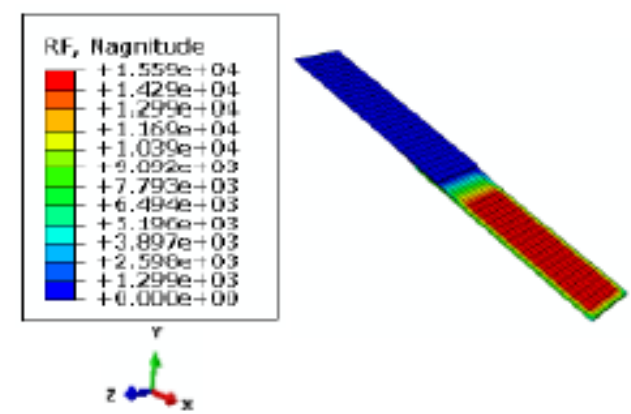

Figure 19 Reaction force of single lap joint with adhesive (epoxy polymer) connection due to static loading

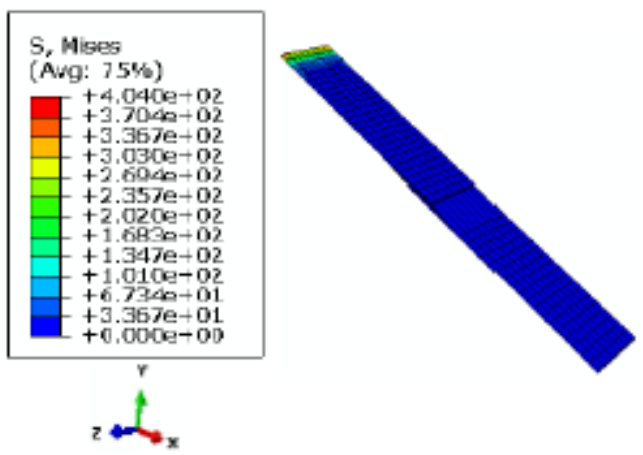

Figure 20 Stress distribution of single lap joint with adhesive (epoxy polymer) connection due to static loading

The degradation of adhesive joint is begun at the ends of the joint, then it propagates to the middle until rupture, Figure 21. 


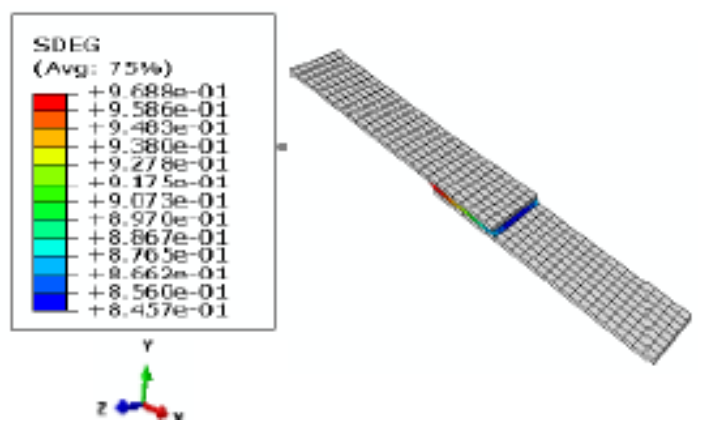

(a)

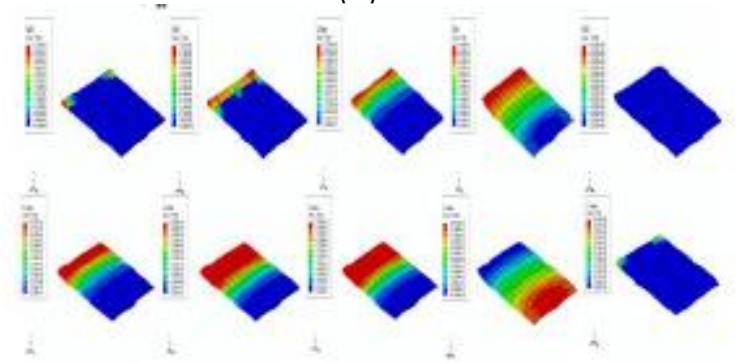

(b)

Figure 21 (a) Damage process of single lap joint with adhesive (polyester resin) connection due to static loading (b) damage process and stress distribution of joint area from first until final step (left to right direction)

\subsubsection{Combination Joint of Screw With Adhesive}

\section{Combination Joint of Screw with Epoxy Resin Adhesive}

On a combination joint, the screw is no longer considered as "screw" but his behavior is considered as a bolt or welding. It is caused by a monolithic bond between screws and adhesive which is stronger to resist rotation. Displacement control of $5.89 \mathrm{~mm}$ (Figure 22) gives the parameters static response of $11054.9 \mathrm{~N}$ reaction force (Figure 23) and $1128.13 \mathrm{Mpa}$ of Von Mises stress (Figure 24).
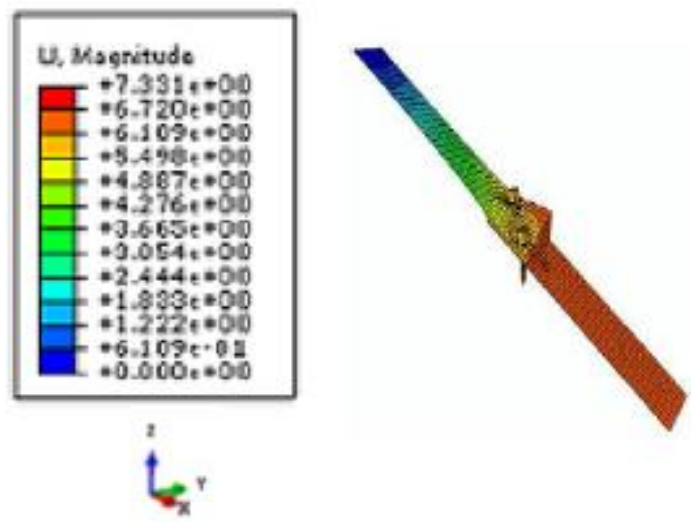

Figure 22 SLJ deformation the combination joint of screw with epoxy resin adhesive

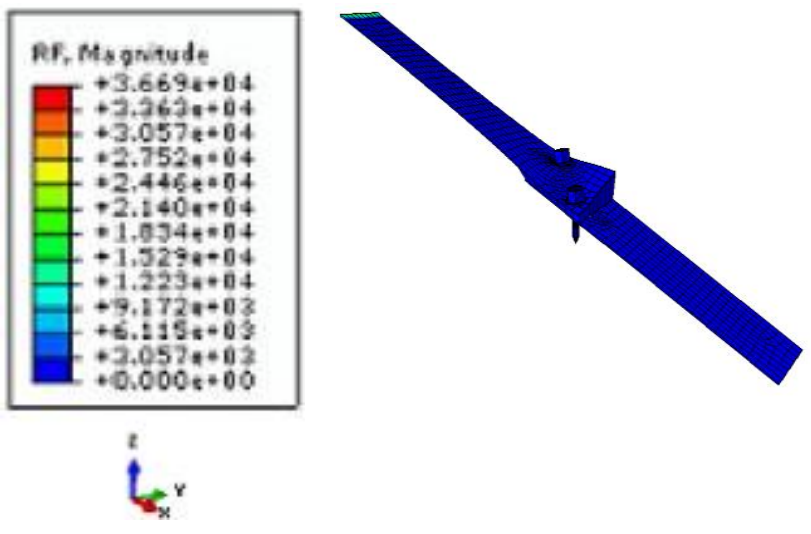

Figure 23 SLJ reaction force the combination joint of screw with epoxy resin adhesive

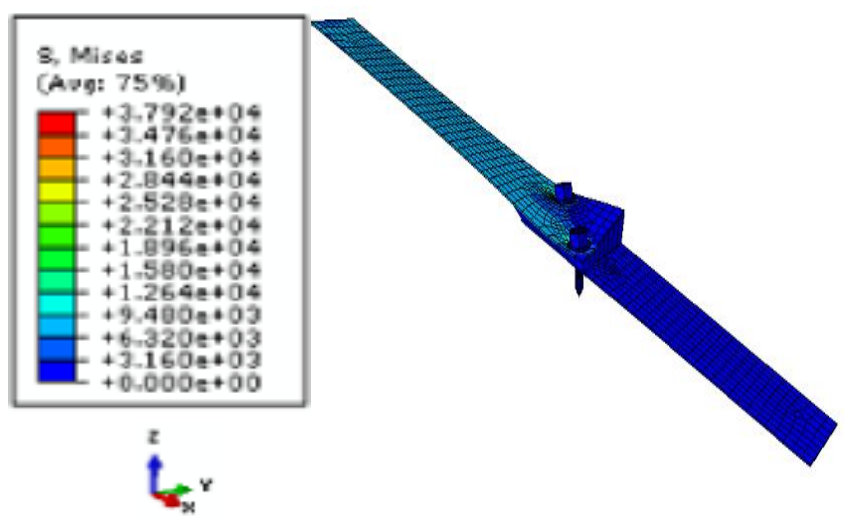

Figure 24 SLJ distribution stress the combination joint of screw with epoxy resin adhesive

Similar to adhesive joint, the joint damage on combination joint the screw with epoxy resin adhesive is began at the ends of adhesive layer then propagates to the middle until rupture, Figure 25.
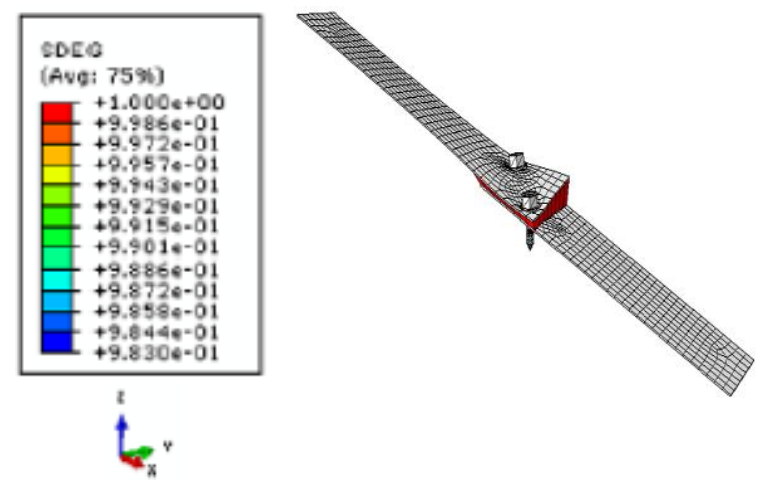

(a) 

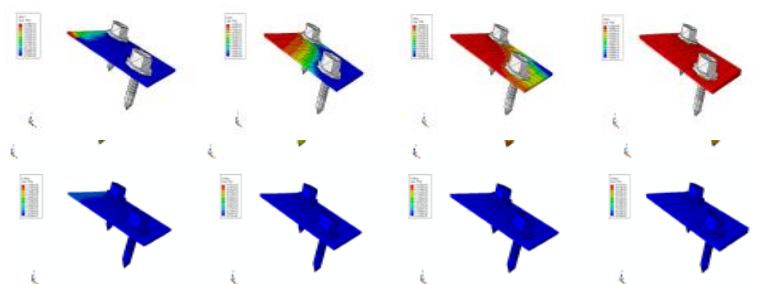

(b)

Figure 25 (a) Damage process of single lap joint with combination connection (screw and epoxy resin adhesive) due to static loading (b) damage process and stress distribution of joint area from first until final step (left to right direction)

Combination Joint of Screw with Polyester Resin Adhesive

While the reaction force and Von Mises stress of SLJ with combination joint (screw and polyester resin adhesive) using displacement control of $4.64 \mathrm{~mm}$ (Figure 26) were $8998.97 \mathrm{~N}$ (Figure 27) and 918.32 Mpa (Figure 28) respectively.
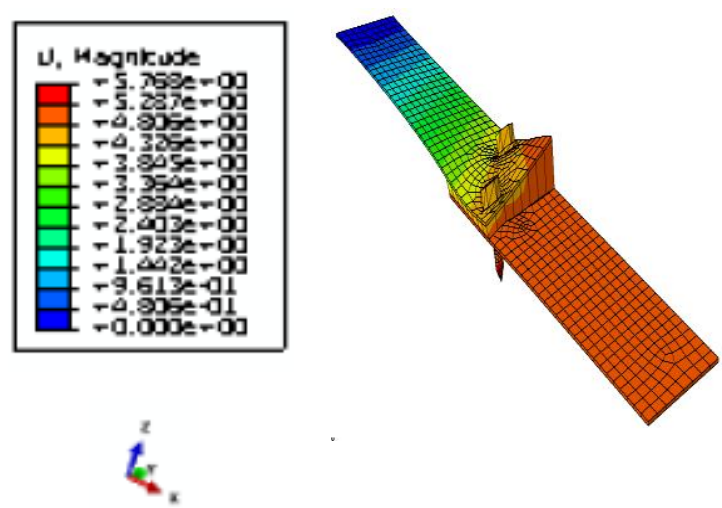

Figure $26 \mathrm{SLJ}$ deformation the combination joint of screw with polyester resin adhesive
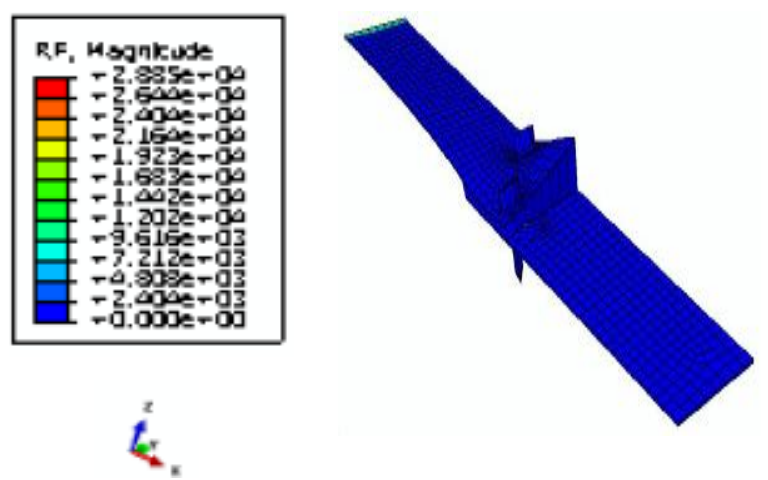

Figure $27 \mathrm{SLJ}$ reaction force the combination joint of screw with polyester resin adhesive

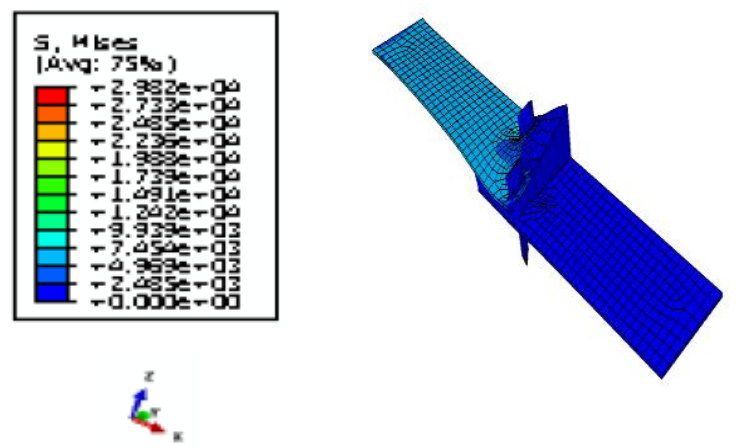

Figure 28 SLJ Distribution Stress The Combination Joint Of Screw With Polyester Resin Adhesive

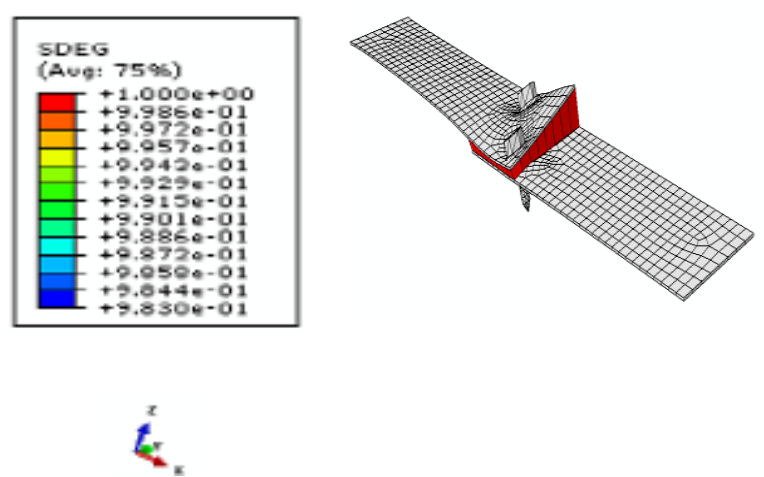

(A)

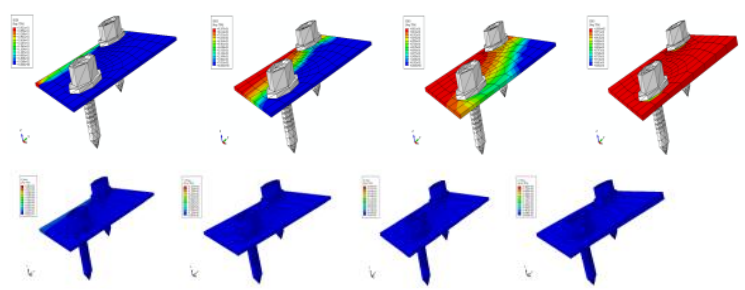

(B)

Figure 29 A) Damage Process Of Single Lap Joint With Combination Connection (Screw And Polyester Resin Adhesive) Due To Static Loading (B) Damage Process And Stress Distribution Of Joint Area From First Until Final Step (Left To Right Direction)

The joint damage on combination joint the screw with polyester resin adhesive is began at the ends of adhesive layer then propagates to the middle until rupture, figure 29. the initial crack phase is described by the red spot then it propagates widely until rupture. the red area shows crack propagation is occured. 


\subsection{Discussion}

\subsubsection{Axial Performance of Cold-formed Steel}

In practice, the erection of cold-formed steel structure is carried out by using a self-drilling screw between elements. Tests conducted on the SLJs of cold-formed steel with a length of $40 \mathrm{~mm}$ and a width overlap of 42 $\mathrm{mm}$, resulting in a total area of joints is $1680 \mathrm{~mm}^{2}$.

Although the capacity of the connection between the adhesive and screw could not be compared in parallel as the netto are of connection (An) is not the same, it is necessary to test the capacity of the combination connection (screw+adhesive) considering their advantages. Moreover, considering vibration effect of screw connection, the adhesive could be as a backup automatically when screw's dynamically resistance is weakened. Thus premature collapse of cold-formed steel structural connections could be prevented, according to incremental the connection stiffness with the use of adhesive in the joint areas.

The load capacity are significantly affected by the types of joints to a more uniformly distribution stress of joint area. Load capacity is seen to increase the combination joints from the screw joint or adhesive joint separately. An anomalous on the combination joint of screw and polyester resin adhesive is occurred, the incremental strength is not reached. It is most likely caused by the different types of adhesive material. Polyester resin adhesive is not normally distributed in the joint area by screw drilling, causes a dislocation adhesive connection on resulting a reduction strength of the joint.

\subsubsection{Axially Failure Joint of Cold-formed Steel Structures}

Bearing failure of screw joint due to axially static load was occurred, as shown in Figure 30. Failure occurs in the connection using screw joint, while the adhesive joint failure is cohesive failure (CF). Failure bonding joint is began by initial crack, then propagates to the other direction (crack propagation) at a constant speed (strain) causing fracture of adhesive (disbonding). After the initial crack, the load versus displacement curve becomes non-linear and strain increases rapidly until reaches a maximum point. Further, the crack propagates at a not constant speed until it reaches the center of the joint (connection). Substrates pretreatment affects the adhesive bonding and the load capacity of joints. On the combination joint between screw and adhesive due to axial loading, increment strength of joints occurred significantly. Joint failure only caused by the crack propagation of adhesive as shown in Figure 31.

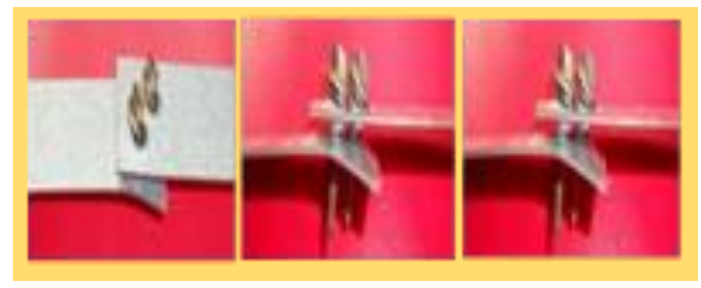

Figure $\mathbf{3 0}$ Joint failure of screw connection due to axially static loading

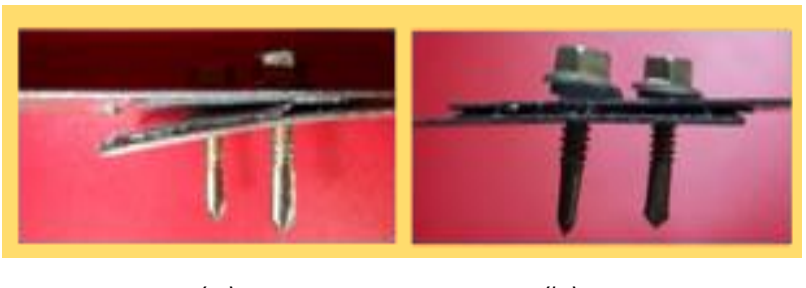

(a)

(b)

Figure 31 Axial failure of combination joint; (a) screw and epoxy resin adhesive, (b) screw and polyester resin adhesive

\subsubsection{FEM Validation to Experimental Work}

A validation the numerical modeling results to experimental work is required to justify the approach that defined in the modeling process. The validation should give a similar behavior and reaction of structures corresponding between them.

Strength Capacity of SLJs with Variety Joint Due to Static Loading

FEM analysis of SLJS with variety joint compare to experimental work is presented on Table 5 and Figure 32. Static strength of FEM has a good enough correlation to the experimental data. An anomalous occurred on the experimental results of combination joint using screw with polyester resin adhesive, which is the strength decreased significantly; that is not similar behaviour to combination joint using screw and epoxy resin adhesive. The lower viscosity of epoxy polymer caused a few of adhesive move out from joint area when screw drilling process.

Table 5 Load capacity of axial joints by experimental and finite element modeling (FEM)

\begin{tabular}{|l|c|l|c|}
\hline \multirow{2}{*}{ Type of Joint } & \multicolumn{3}{c|}{ Ultimate Load, Pu (N) } \\
\cline { 2 - 4 } & Experimental & FE Modeling & (\%) \\
\hline Screw & 6240 & 4871.57 & 21.93 \\
\hline Epoxy resin adhesive & 6650 & 7880.48 & 18.50 \\
\hline Polyester resin adhesive & 12450 & 7889.48 & 36.63 \\
\hline $\begin{array}{l}\text { Combination the screw and } \\
\text { epoxy resin adhesive }\end{array}$ & 12630 & 11054.9 & 12.47 \\
\hline $\begin{array}{l}\text { Combination the screw and } \\
\text { polyester resin adhesive }\end{array}$ & 8650 & 8998.97 & 4.03 \\
\hline
\end{tabular}


Strength capacity deviation of experimentation to FEM are $21.93 \%, 18.5 \%, 36.3 \%, 12.47 \%$ and $4.03 \%$ for srew, epoxy resi adhesive, polyester resin adhesive, combination screw with epoxy resin and combination screw with polyester resin connections.

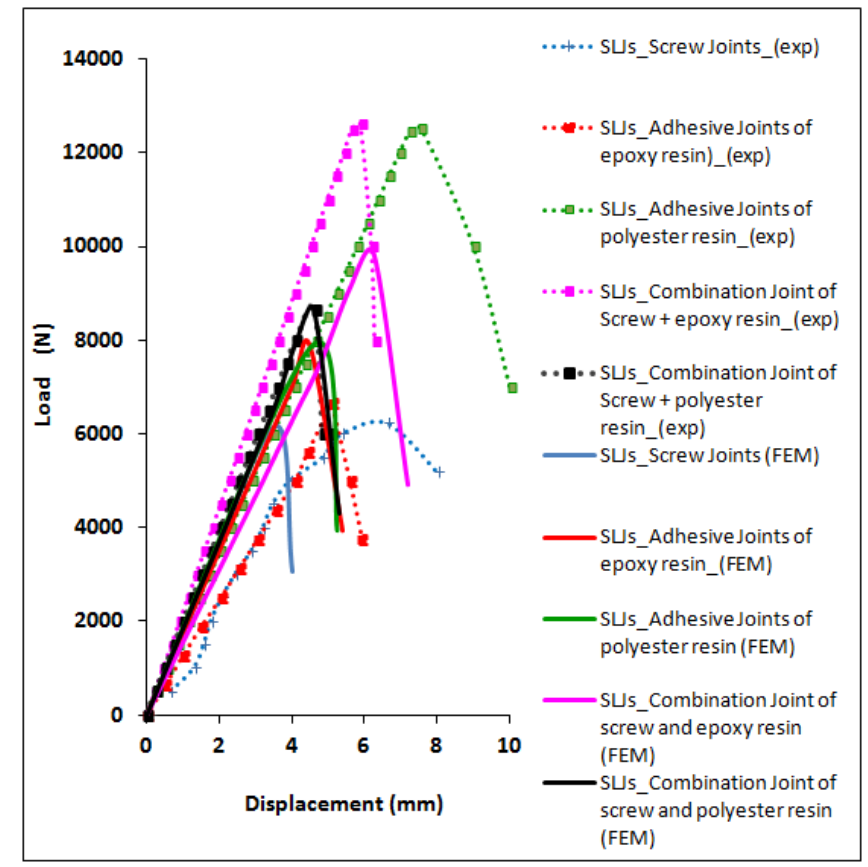

Figure 32 FEM validation (a) to experimental work of SLJ with variety joint due to axially static loading (b)

\section{Failure Process Zone (FPZ)}

FPZ's path length was taken as cohesive element as long as $42 \mathrm{~mm}$ width. FPZ is defined as the material damage zone by various failure mechanisms on several levels of material structure. Initial damage of adhesive joint was begun by crack initiation then it propagated until joint failure. Every joint types has a natural failure mechanism, which is different each others. It affects the load capacity of the joints (Figure 32). The damage process on adhesive joint was faster than on combination joint, that is identified by scalar degradation (SDEG) value of $0.3-0.5$ and $0.9-1.0$ respectively.

Damage of adhesive connections are normally distibuted as long as FPZ. It is caused by cohesive element of the connection area. But, damage of combination connections are not normally distibuted as long as FPZ because there are continuum elements (screw) at the connection area.

The joint damage (cohesive zone, CZM) was begun at the end of linearly load-displacement chart; that is called initial crack phase. Then displacement increase quickly until maximum point of load-displacement curve, or crack propagation. Finally the damage process was terminated when disbonding (failure) was occurred.

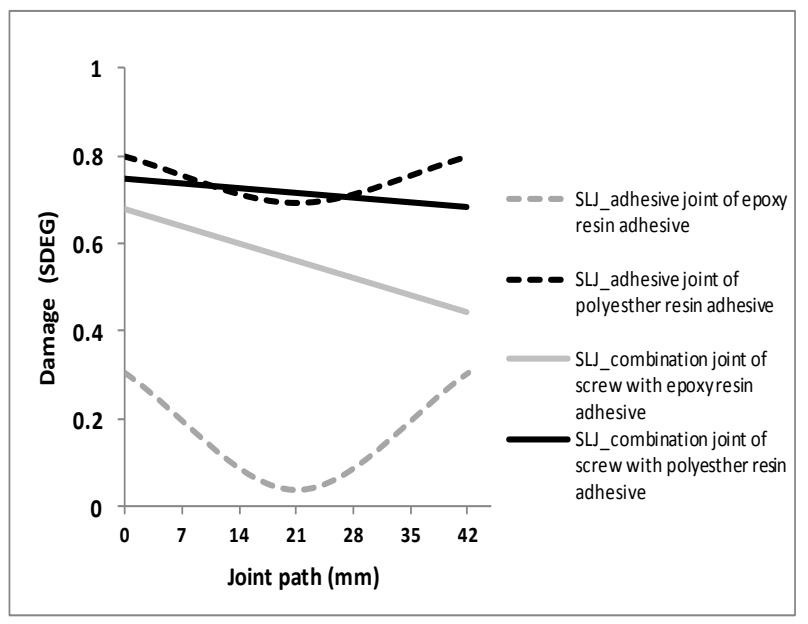

Figure 33 Damage's distribution on the joint area of SLJ due to axially static loading

\section{Stress Distribution}

Stress distribution of screw joint was correlated to deformation distribution. Stress distribution on joint width was uniform, but it was not uniform on joint length by boundary conditions of support. Stress concentration occurred surrounding the screw's hole, that were the effects of a residual stress of drilling screw and decrement of joint area to support load, Figure 34.

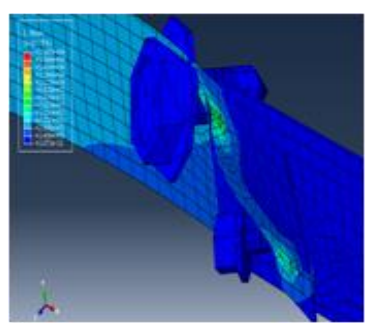

Figure 34 Stress distribution on the screw joint of SLJs due to axially static loading

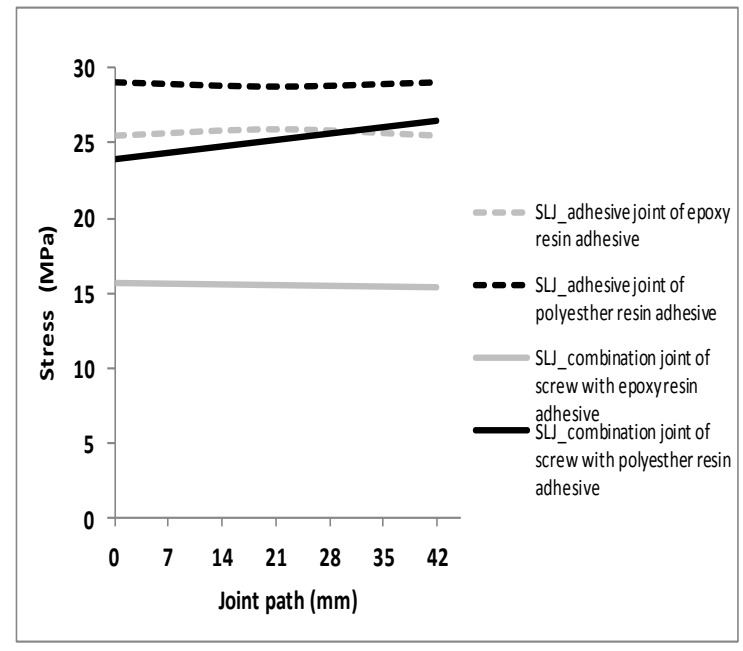

Figure 35 Stress distribution on the adhesive joint and combination of SLJs due to axially static loading 
Stress distribution the adhesive joint and combination were correlated to damage distribution on the joint area. Stress distribution on adhesive joint width was normally distributed, but it was not normally distributed on combination joint width by screw constraints. Pure cohesive elements at connection area cause the normally distributed stress as well. Otherwise, continuum elements at connection area cause unormally distributed stress, Figure 35.

\subsection{CONCLUSIONS}

Adhesive joint of SLJs due to axially static loading have a good performance, rather than screw joint. Combination joint between screw and adhesive on cold-formed steel structure could prevent premature collapse of the structure. Adhesive in the combination joints can minimize the pull-over failure of screw. It was caused by the rigidity cold-formed steel structure was increased through the adhesive joint. The joint strength of adhesive was affected by the types of adhesives. The joint failure began at the end of adhesive area then propagates to the middle until fully degraded. Strength capacity is increased by $7 \%, 99 \%, 102 \%$ and $39 \%$ for epoxy resi adhesive, polyester resin adhesive, combination screw with epoxy resin and combination screw with polyester resin connections; compared to screw connection's capacity. .

FEM analysis using CZM approach has a good correlation to the experimental works. Cohesive element was described clearly the damage process of adhesive in the joints. FEM's simulation also showed the monolithic connection of screw into substrates by the adhesive, it is an issue to prevent the premature collapse of cold-formed steel structures with screw joint. Strength capacity deviation of experimentation to FEM are $21.93 \%, 18.5 \%, 36.3 \%, 12.47 \%$ and $4.03 \%$ for srew, epoxy resi adhesive, polyester resin adhesive, combination screw with epoxy resin and combination screw with polyester resin connections.

\section{Acknowledgments}

Authors are grateful to the Structure Laboratory of Institut Tecknologi Sepuluh Nopember (ITS) and Mulcindo Steel Company of Surabaya Indonesia for the supporting experimental works.

\section{References}

[1] Anwar, S. N. R., Crocombe, A. 2013, Simultaneously Effect of Environment and Sustained Load on the Degradation of
Aluminium Bonded Joint. International Journal of Materials Science and Applications. 2(6): 204-208.

[2] Ganesan, K., C. D. Moen. 2012. Load Resistance Factor for Cold-Formed Steel Compression Members. Journal of Constructional Steel Research. 72: 261-266.

[3] Galambos. 1987. Guide to Stability Design Criteria for Metal Structures. 4th Edition. John Wiley \& Sons.

[4] Haidarali, M. R., D. A. Nethercot. 2011. Finite Element Modeling of Cold Formed Steel Beams under Local Buckling Combined Local/Distortional Buckling. Journal of Thin-Walled Structures. 49: 1554-1562.

[5] Mutawalli, M. 2007. Stability of Cold Formed Steel Frame Connection Type T to Cyclic Loading on the Knock Down of Simple House. Postgraduate Thesis. Universitas Gadjah Mada, Yogyakarta, Indonesia.

[6] Moen, C. D., T. Igusa, B. W. Schafer. 2008. Prediction of Residual Stresses and Strains in Cold-Formed Steel Members. International Journal of Thin Walled Structures. 46: 1274-1289.

[7] Yu, W. W. 1999. Cold-Formed Steel Structures. Structural Engineering Handbook. CRC Press LLC.

[8] Young, B., J. Chen. 2008. Column Tests of Cold-Formed STeel Non-Symmetric Lipped Angle Sections. Journal of Constructional Steel Research. 64: 808-815.

[9] Adams, R. D. 2000. Adhesive Bonding Science Technology and Aplications. CRC Press, Woodhead Publishing Limited.

[10] Adam, R. D., J. Comyn, C. W. Wiliam. 1997. Structural Adhesive Joints in Engineering. Saffron Walden ESS United.

[11] Harris, A. F., A. Beevers. 1999. The Effect of Grit-Blasting on Surface Properties for Adhesion. International Journal of Adhesion and Adhesives. 19: 445-452.

[12] Knox, E. M., and M. J. Cowling. 2000. A Rapid Durability Test Method for Adhesives. International Journal of Adhesion and Adhesives. 20: 201-208.

[13] Kim, Brontman. 1971. Yield and Fracture of Polymers. 4th International Conference of Deformation, Cambridge.

[14] Lim, J. B. P., D. A. Nethercot. 2004. Stiffness Prediction for Bolted Moment Connections between Cold-Formed Steel. Journal of Construction Steel Research. 60: 85-107.

[15] Naito, K., M. Onta, Y. Kogo. 2012. The Effect of Adhesive Thickness on Tensile and Shear Strength of Polyimide Adhesive. International Journal of Adhesion and Adhesive. 36: 77-85.

[16] Setiyawan, P., M. H. Osman, A. A. Saim. 2012. Strength and Rigidity of Strengthened Cold-Formed Steel Moment Connection. APSEC-ICCER Conference, Surabaya, Indonesia.

[17] Anwar, S. N. R., P. Suprobo, E. Wahyuni. 2015. Axial and Flexural Performance the Adhesive Joint and Combination on Cold-formed Steel Structures. International Journal of Technology. 6(4): 699-708.

[18] Anwar, S. N. R., P. Suprobo, E. Wahyuni. 2014. Tensile Performance of Adhesive Joint on The Cold-Formed Steel Structures. International Journal of Engineering Trends and Technology. 10(5): 231-234.

[19] American Standard of Testing Materials D 695. 2006. Standard Test Method for Compression Properties of Plastic, Annual Book of ASTM Standards, American Society for Testing and Materials.

[20] American Standard of Testing Materials E 8. 2006. Tension Testing of Metallic Materials, Annual Book of ASTM Standards, American Society for Testing and Materials.

[21] Anwar, S. N. R., P. Suprobo, E. Wahyuni. 2013. Modelling of Adhesive Joint on Cold-Formed Steel Subjected to Flexural Loading. Proceeding of 6th Civil Engineering Conference in Asia Region, Jakarta, Indonesia. Paper 186. 